\title{
Culture Shock Experienced by Foreigner in Makassar
}

\author{
Husnul Khatimah \\ husnuulkhatimah@gmail.com
}

\begin{abstract}
English Education Department, Faculty Of Teacher Training And Education,
\end{abstract} Muhammadiyah University of Makassar, Indonesia

Received: August 3, 2020

Received in Revised: August 11, 2020

Accepted: August 13, 2020

\begin{abstract}
The phenomenon of culture shock is part alive of people who attracts to know culture shock or feel unfamiliar with local culture. This study aimed at describing the culture shock experienced by foreigners during their stay in Makassar city. Several cultural shock in Makassar is language, the way of wearing cloth, food, and. This kind of behavior is primary behavior Makassar's people. The foreigner try to adapt by observing and try to why they look lite that. After knowing they can enjoy with this problem.
\end{abstract}

Keywords: Culture Shock, Foreigner, Phenomenon

\section{Introduction}

Culture shock is a condition that individuals as an immigrant in some places that experienced displeasure or does not meet expectations on the applicable habits or traditions of a place. Culture is closely connected to the community.

The term culture originated from the Latin word "cultura" that stems from the verb "colere"e meaning to cultivate. Culture is a vague concept, which includes extensive content such as sight, smell, sound, value, tradition, custom behavior, and the way of thinking (Xia, 2009). In the eighteen century, the meaning of culture was linked to agriculture. In the nineteenth century, the term became used in association with an individual and his or her education, and in the twentieth century, it became a center of the concept of anthropology (Crhanova, 2010).

Moreover, Mahadi and Jafari (2012) defined culture is the total of the inherited and innate ideas, attitudes, beliefs, values, and knowledge, comprising or forming the shared foundations of social action. Besides that Rocsher (Mahadi and Jafari, 2012) defined culture is the connection of ideas and feelings accepted by the majority of people in a society. According to Edward Burnett Tylor, culture is a complex whole, which has in the knowledge, belief, art, morals, law, customs, and other abilities of any persons of a member of society. Based on the references above, the researcher concludes that culture is all of the inherited which includes extensive content such as behavior, smell, sound, value, tradition, custom behavior, and the way of thinking that accepted and adopted by the majority of people in a society/community.

Suryandari (2012) states that "culture shock is a phenomenon that will be experienced by everyone who crossed from one culture to another as a reaction as they move and live with people of different clothes, tasted, value, even with a language that belongs to the people".

Moreover, Bennett (1998) define culture shock is primarily a set of emotional reactions to the loss of perceptual reinforcements from one ${ }^{\text {ee }}$ own culture, to new cultural stimuli which have little or no meaning, and to the misunderstanding of new and diverse experiences.

Furthermore, according to Indrianie (2012) Culture shock describes the psychological state of the negative, passive reaction of individuals dealing with different cultural environments. 
The phenomenon of culture shock is part of alife of people who attract to know culture shock or feel unfamiliar with local culture, it is a problem that often happens to a person. Indeed, this problem is not directly threatening, but if not handled properly can lead to a serious matter in the future. Culture can make the foreigner feel uncomfortable and even depression when they solve in the bad condition

Based on the statement above culture shock experienced by a person who comes from outside or another country to the region. Because foreigners are always exited and interesting with something new and unique, it makes them attracted and defiance to visit tourist places overseas. Especially come to Indonesia that have diverse cultures and interesting place with a beautiful view. There are various reasons that make them feel at home during a stay in Indonesia. The potential natural beauty of this country and her polite natives are a few small things that the background for them at home (Jaelani, 2017).

Makassar is one of the cities in South Sulawesi and one of the unique cities with culture. As the town has a wide range of tourist places attract the attention of foreigners to visit the city. probably, some of them had chosen to stay in the city of Makassar. Foreign tourists visit began to show a positive trend. In 2018, the total foreign tourists had reached 2.605.334 people.

If in their country, have been accustomed to people who behave or the same behavior with them, but it will be different from the native people they met in Makassar city. They will face a lot of distinguishing things such as behave, how to dress, how to talk, food, language, and values are different. The incident is called culture shock. Based on this problem, the researcher is interested in describing the culture shock experienced by foreigners during their stay in Makassar city.

\section{Results and Discussion}

In this part of findings to answer the research questions which show culture shock experienced by foreigners in Makassar city. Ward \& Kennedy (2001) explain that the process of culture shock can be described as consisting of four distinct phases: Honeymoon, crisis, recovery, and adjustment, through U-curve theory. Through this model, two effects of culture shock happen such native and positive

\section{Honeymoon}

The person experienced this phase from the beginning of first moving to the new environment. In this phase, foreigners still feel happy and enjoyed the condition. Foreigners had no problems with the new environment yet.

\section{Hospitality}

Some foreigners experienced honeymoon phases because of the hospitality they said that Makassar"s people very polite.

"Makassar's people very polite and friendly, it's very different in Germany, like you, your language is very polite when you offering help or meet in the first time" (P, 2019)

\section{Scenery}

The bold datum showed that foreigners experienced the honeymoon phase because of the scenery. It represented by Foreigner 1 and 2. she said that:

"It's okay.... Makassar is beautiful, expecially in malino, we can take a beautiful view" ( K, 2019). 
"I like the view. I think Indonesia is a beautiful country." (P,2019)

\section{Crisis}

This phase is like negative case that was get by the foreigners when their own country was different from the new country. In this phase, the foreigners get some problems that make them unsuitable in the new thing environment.

a. Language

The bold datum below showed that foreigners experienced the crisis phase because different language of the host culture.

"I think the language is very difficult, I can't understand the language but am trying to learn" (P, 2019).

“mm the language. Sometimes I don't understand when makassar's people talk to me, expecially when they use Makassar is language (K, 2019).

Based on the research above e was confusion. Even they want to learn in it. But still difficult to understand the language. It is in negative effect of culture shock.

b. The way in wearing dress

The bold datum below showed that foreigner experienced the crisis phase because different way in wearing dress of the host culture, it is represented by foreigner . she said that:

"almost women wearig like sarong in their head, mmm how to say. Oh yeah veil, it's new experiences because in Germany State almost nobody wearing (P, 2019 ).

"actually am happy in Indonesia because most of the women wearing veil, because am also as a moeslim, I think it's a polite dress and it's very different in Singapore", (K, 2019)

The answer for the foreigner above showed that it is the confusion. It is a bit negative effect of culture shock.

c. Food

The explanation below showed that foreigner experienced the crisis phases because the food in the host culture. It is represented by foreigner :

"food is different. You have spicy food that... so much spiced for me l" (P, 2019).

"I like rendang, you know rendang right? Also mie goreng. But the way to cook is different in Singapore. $(K, 2019)$

The explanation above showed that it is feeling different taste of food. It is in negative effect of culture shock.

\section{Recovery}

In this phase, the person began to resolve and learned about the differences culture in the host culture.

a. Language

The answer conversation below showed that foreigner experienced the recovery phase. Foreigner began to learn and understood about the language of the host culture. It represent by the foreigner 1 . She said that: 
"The Indonesian language, actually bit hard but I can solve a little bit by Google translation or use gesture . for the first time" (P, 2019).

The research above showed that it is the life change. It is in positive effect of culture shock.

\section{The way in wearing dress}

The example below showed that foreigner experienced the recovery phase. Foreigner began to understand about the way in wearing dress. It represent by foreigner 2 . she said:

"for the first time I came here I feel shocked about the women in wearing Clothes. But.. mmm I asking my friend .. yeah she said In Indonesia almost Moslem...and like in Makassar also... yeah I can understood. am also as a moeslim” (K, 2019)

The explanation above showed that it is the life change. It is in positive effect of culture shock.

\section{b. Food}

The explanation below showed that foreigner experienced the recovery phase. Foreigner began enjoy the food in the host culture it represented by foreigner 1. Sshe said that:

"The food problems.. well... before I tested anything I'm trying to know what are they, how they make it, then after then I' eating them like noodle. Wah very nice ( $K$, 2019).

\section{Adjustment}

In the last phase, individuals enjoyed all the differences and difficulties of the new culture in new environment.

\section{a. Language}

The result of observation below showed that foreigners experienced the adjustment phase. The way have known and understood little bit Indonesian and Makassar language it represent by paula

"I think is very difficult but I love it to learning. Now I can Speak Indonesian language. I can understand Makassar language also, but still I"m trying to learning." $(P, 2019)$

The datum above showed that it is life change. It is in positive effect of culture shock.

b. The way of wearing dress

The bold datum below showed that foreigners experienced the adjustment phase. They have been enjoyed foreigner have been enjoyed facing the woman did use the veil. It represent by khairani .

"hmm no. I mean... now I haven't any problem anymore about the way in wearing clothes because it was as usual for me." (K, 2019).

The explanation above showed that it is the life change. It is in positive effect of culture shock.

c. Food

The bold datum below showed that foreigners experienced the adjustment phase. They were accustomed and enjoy the tested of food of the host culture. It represented by foreigner 2 . She said that: 
"hmmm.. about the food.. yeah especially the spicy food and noole ... mmm maybe it become as usual.. because I've been enjoy the food the spicy food $(K, 2019)$

The datum above showed that it is the life change. It is in positive effect of culture shock.

Based on the observation by interview the foreigner, some of foreigner who come to in Indonesia, expecially in Makassar get several cultural such as, different language, foods, behaviour and etc. because there are several things that make them shocked because in is firs time they see like new food, shear new language.

all of foreigners as informants experienced the honeymoon phase because of the hospitality. The hospitality of Makassar people was made the foreigners amazement and happy for the first time they came in Makassar city.

The foreigner for the first time, probably feel uncomfortable with the new thing that they faced, but they try adaptate with makassar's people. They know that makassar'society is polite and lso friendly. they met people of Makassar, she excited to see the good habitually such wshen they mutual gaze with somebody always got a smile. And it's different in their country, like what paulasa that "Makassar society is very polite and I'm really happy being shere".

Language barriers and behaviour costums are the major problem for the foreigners wshen they are in the new culture. They were depressed and homesick due to lack of language and different costumes and it caused them to feel isolated in their new environment. Most of people in Makassar are Moslem, it means most of women in Makassar wearing veil as dress code of Moslem religion. It made some foreigners shocked and confused for the first time they see the condition.

Foreigner as sojourners will eat the different food in the host country. It represented she felt the foods in Makassar is so spicy it ${ }^{\text {ee }}$ so difficult for him for the first time she stay in Makassar city.

\section{Conclusion}

Cultural shock is a new thing that faced of the foreigner when they come to overseas. While they try to adapt to them. Several cultural shock in Makassar is language, the way of wearing cloth, food, and. This kind of behaviour is primarily behaviour Makassar's people. The foreigner try to adaptate by observing and try to why they look lite that. After knowing they can enjoy with this problem.

\section{References}

Bennett, M. J. (1998). Intercultural communication: A current perspective. Basic concepts of intercultural communication: Selected readings, (1), 1-34.

Crhanová, I. (2011). Culture shock (Doctoral dissertation, Masarykova univerzita, Pedagogická fakulta).

Indrianie, E. (2012). Culture Adjustment Training untuk Mengatasi Culture Shock pada Mahasiswa Baru yang Berasal dari Luar Jawa Barat. Jurnal Insan, 14, 150-151.

Jaelani, A. (2017). Halal tourism industry in Indonesia: Potential and prospects. International Review of Management and Marketing, 7(3).

Mahadi, T. S. T., \& Jafari, S. M. (2012). Motivation, its types, and its impacts in language learning. International Journal of Business and Social Science, 3(24). 
Suryandari, N. (2012). Culture Shock Communication Mahasiswa Perantauan Di Madura. Universitas Trunojoyo Madura.

Ward, C., \& Kennedy, A. (2001). Coping with cross-cultural transition. Journal of crosscultural psychology, 32(5), 636-642.

Xia, Junzi 2009. Analysis of Impact of Culture Shock on Individual Psychology. International Journal of Psychological Studie.Vol 1, No.2. China: Ningbo.

http://dx.doi.org/10.5539/ijps.v1n2p97. 